\title{
Études/Inuit/Studies
}

WILLIAMSON, Karla Jessen, 2011 Inherit my heaven: Kalaallit gender relations, Nuuk, Naalakkersuisut/ Government of Greenland, and Inussuk Arctic Journal, 1, 208 pages

\section{Joanna Kafarowski}

Volume 37, numéro 2, 2013

URI : https://id.erudit.org/iderudit/1025719ar

DOI : https://doi.org/10.7202/1025719ar

Aller au sommaire du numéro

\section{Éditeur(s)}

Association Inuksiutiit Katimajiit Inc.

Centre interuniversitaire d'études et de recherches autochtones (CIÉRA)

\section{ISSN}

0701-1008 (imprimé)

1708-5268 (numérique)

Découvrir la revue

Citer ce compte rendu

Kafarowski, J. (2013). Compte rendu de [WILLIAMSON, Karla Jessen, 2011

Inherit my heaven: Kalaallit gender relations, Nuuk, Naalakkersuisut/ Government of Greenland, and Inussuk Arctic Journal, 1, 208 pages]. Études/Inuit/Studies, 37(2), 206-208. https://doi.org/10.7202/1025719ar d'utilisation que vous pouvez consulter en ligne. 
ISSENMAN, Betty Kobayashi

1997 Sinews of Survival: The Living Legacy of Inuit Clothing, Vancouver, University of British Columbia Press.

OAKES, Jillian E.

1991 Copper and Caribou Inuit Skin Clothing Production, Hull, Canadian Museum of Civilization, Canadian Ethnology Service, Mercury Series, 118.

Bernadette Driscoll Engelstad

Research Collaborator

Arctic Studies Center

Department of Anthropology

Smithsonian Institution

P.O. Box 37012

Washington, D.C., 20013-7012, USA

bengelstad@aol.com

\section{WILLIAMSON, Karla Jessen}

2011 Inherit my heaven: Kalaallit gender relations, Nuuk, Naalakkersuisut/ Government of Greenland, and Inussuk Arctic Journal, 1, 208 pages

The modest literature on gender issues in the Circumpolar North is dominated by the contributions of non-Indigenous scholars, with notable exceptions including Sami scholars Elina Helander-Renvall, Jorunn Eikjok, and Rauna Kuokkanen. Their work is complemented by research conducted by representatives of community and national organisations, such as Pauktuutit, the Inuit Women's Association in Canada, and Sáráhkká, the Sami Women's Association in Scandinavia. Karla Jessen Williamson, a self-identified Kalaaleq from Maniitsoq in Greenland, who has lived most of her adult life in Canada, has published several articles on gender, most notably in Etudes/Inuit/Studies and in the gender chapter of the first Arctic Human Development Report. Inherit my heaven: Kalaallit gender relations published in Inussuk Arctic Journal is derived from Williamson's doctoral dissertation on Inuit gender relations in a post-colonial Greenland community, which was submitted to the University of Aberdeen. It represents one of the most comprehensive explorations of gender in Inuit society by an Indigenous researcher and, as such, is worthy of examination.

Williamson challenges "the perception that the Arctic is a male-preferential world, and that, therefore, arctic women must suffer doubly under male dominance and under colonization in comparison with the women in the south" (p. 8). Rejecting the relevance of Western-based concepts of gender inequality, she relates that Inuit describe themselves as human beings and individuals first before making gender distinctions. She states that a defined division of roles and responsibilities for Inuit women and men exists but contends that this division is flexible, allowing for role reversal when appropriate or necessary. This division creates complementary roles and 
mutually beneficial relationships that contribute to an efficient and democratic society. Williamson adopts the concept of "genderlessness" to reflect the egalitarian nature of Inuit society. This concept is examined through three linked categories: 1) all animate and inanimate beings and objects are imbued with sila or a life-giving energy and intelligence in which gender is irrelevant; 2) gender is absent from traditional Inuit naming practices or aqqi in which the names, spiritual nature, and other qualities of ancestors and relatives who have died are bestowed upon newborns; and 3) the Inuktitut language omits "prominal genderization" in that it does not include the words "she," "he," and "it." Williamson states that the concept of "genderlessness" within Inuktitut is exemplified through accordance of equal value and rights to all beings regardless of sex. She asserts that this "emphasizes the essential basic humanity of the human being, though expressed in the male and female physiology of both" (p. 9).

Williamson criticises the philosophical underpinnings (aqaatsit) of Western feminist thought as being too androcentric and narrow. She argues instead that pinngortitaq, which is defined as "the environment, the habitat, or the totality of the world or creation perceived in the context of the universe" (p. 42), is a more relevant and useful tool to assess gender within Inuit society. Furthermore, Williamson contends that Inuit use timikkut (the body), anersaakkullu (the spirit) and tarnikkut (the name/soul) as a lens through which to view the world. She states: "These physical and spiritual qualities are closely associated with the Inuit notion of genderlessness: any Inuk is philosophically empowered regardless of their gender. This goes beyond equality between men and women: the triadic structure is to be applied to all of life; it is the framework of Inuit knowledge" (p. 62). Using the concept of "genderlessness" and applying the framework of timikkut, anersaakkullu, and tarnikkut, Williamson delves into gender, childhood, and sexuality; the gendered division of labour in the public and private spheres; women and development; and violence and gender.

Williamson gathered her data over a period of several months in 1998 in Maniitsoq, Greenland. Her fieldwork involved only seven research participants, including family members. Thus, her conclusions can only be described as suggestive. Participatory action research is adopted as the methodological framework. While this seems a logical choice, Williamson does not present a convincing argument for doing so. In particular, her references to the scholarly literature on participatory action research are rather sparse and the bibliography somewhat outdated. Minimal demographic information is provided and phrases such as "very few [of the participants] were young" inhibit contextualisation of the data and a richer understanding of the results. Although the author may not have deemed this information relevant enough to include in the text, it could have been referenced in an appendix. Additionally, not only a wider but also a more representative sampling that included more field sites would likely have yielded richer results. Despite these shortcomings, Inherit my heaven: kalaallit gender relations introduces an innovative approach to studying gender issues in the Circumpolar North. Its publication will hopefully encourage other much-needed contributions by other Indigenous scholars working in this field. 
Joanna Kafarowski

61 Highland Lane

Richmond Hill, Ontario L4C 3S1, Canada gypsy_four@hotmail.com 